\title{
Otel İşletmeleri Çalışanlarında İş Doyumunun Çalışanların Tükenmişlik Düzeyine Etkisi: Kuzey Kıbrıs Örneği
}

\section{The Impacts of Job Satisfaction on the Burnout Levels of Employees Working in Five Star Hotels: Northern Cyprus Case}

Yrd.Doç.Dr. İbrahim ÇETiN

Yüzüncü Yıl Üniversitesi

Turizm ve Otel İşletmeciliği YO

E-posta: ibrahimcetin01@yahoo.com

Orcid Id: 0000-0003-2210-0101
Yrd.Doç.Dr. Onur içöz

Adnan Menderes Üniversitesi

Turizm Fakültesi

E-posta:onur.icoz@adu.edu.tr

Orcid Id: 0000-0002-0775-1451

\section{Öz}

$\mathrm{Bu}$ çalışmanın amacı, turizmin en fazla istihdam yaratan hizmet alanı olan konaklama sektöründe çalışanların "iş (mesleki) doyumları" ile işgörenlerin en önemli sorunlarından birisi olan "mesleki tükenmişlikleri" arasındaki ilişkilerin belirlenmesi ve açıklanmasıdır. Araştırma evreni olarak Kuzey Kıbrıs Türk Cumhuriyeti'ndeki 5 yıldızlı otel çalışanları belirlenmiştir. Çalışmada veri toplama aracı olarak kullanılan anket formlarının oluşturulmasında Minnesota Doyum Ölçeği ve Maslach Tükenmişlik Ölçeği'nden yararlanılmıştır. Elde edilen sonuçlara ve bulgulara göre, "Işs Doyumu" ile "Mesleki Tükenmişlik" arasında negatif bir ilişki tespit edilmiştir. Ayrıca, "iç Doyum ve Duygusal Tükenmişlik" ile "iç Doyum ve Duyarsızlaşma" ilişkilerinin negatif, "İç Doyum ve Kişisel Başarı" ilişkilerinin de pozitif olduğu belirlenmiştir. Yine, "tükenmişlik" ve "iş doyum" arasında negatif yönlü bir ilişki bulunmuştur. Çalışanların iş doyum düzeylerinin görev yapılan bölüme ve çalışma süresine göre anlamlı farklılıklar gösterdiği de tesbit edilmiştir.

Anahtar Kelimeler: İş Doyumu, Tükenmişlik, Otel işletmeleri, Otel çalışanları, Kuzey Kıbrıs.

\begin{abstract}
The purpose of this study is to investigate and explain the relationships between employee job satisfaction and their burnout levels in hotel establishments as the largest employers of tourism sector. Five star hotel employees in The Turkish Republic of Northern Cyprus were identified as the universe of the research. A questionnaire formed by combining "Minnesota Satisfaction Scale" and "Maslach Burnout Scale" was used for data collection of the survey. According to the results; negative relationships were found between "job satisfaction and occupational burnout", "internal satisfaction and emotional burnout" and "internal satisfaction and desensitization", while there were positive relationships between "internal satisfaction and personal success". Meaningful differences between the satisfaction levels of employees were also identified based on their duties and time spent on the job.
\end{abstract}

Keywords: Job Satisfaction, Burnout, Hotel operations, Hotel employees, Northern Cyprus. 


\section{Giriş}

Geçmişten günümüze her alanda meydana gelen gelişmelerin, bazı konuların ya da kavramların geçmişte olduğundan daha farklı bir yaklaşım ve önemle ele alınmasını gerektirdiği anlaşılmıştır. Bu konulardan birisi de işletmelerdeki çalışanlar ve görev yaptıkları işyeri ortamlarıdır. Gerek tarihsel süreç içinde ve gerekse türü ne olursa olsun az ya da çok oranda her işletme için çalışanlar ve emek verenler birer üretim faktörü olarak ve insani değerler açısından önemlidir. Şüphesiz, hizmet üretilen turizm işletmeleri için en önemli faktör, hizmeti meydana getiren çalışanlar olduğundan bu konu daha da önem kazanmıştır. Bu önem çalışanların daha iyi anlaşıımasını, işinden haz elde etmesinin sağlanması, onların motivasyonu, ödüllendirilmesi ve verimliğinin sağlanması için uygun yönetim anlayışlarını da gündeme getirmektedir.

Turizm ve ağırlama endüstrisinin gelişmesi, çeşitli ve benzer işletmelerin pazara girmesi tüketiciler için seçeneklerin artmasına katkı sunarken işletmeler arasında da yoğun bir rekabeti ortaya çıkarmaktadır. İşletmeler için fiyat, ürün, tanıtım ve dağıtım gibi pazarlama karması unsurları bir rekabet aracı olarak görülmekle birlikte, ağırlama endüstrisinin ve dolayısı ile otel işletmelerinin hizmet yapısı, rekabet için en önemli araçlardan birinin otel çalışanları olduğunu ortaya çıkarmaktadır. Günümüzdeki ekonomik ve toplumsal yaşamda meydana gelen değişmeler turizm endüstrisinde önceleri lüks görünen tatil ve bu kapsamda tüketicilerce kullanılan otel işletmelerinin önemini artırmıştır. Bununla birlikte, piyasadaki yoğun rekabet bu işletmelerde çalışanların eskisinden daha önemli olduğu sonucunu ortaya çıkarmıştır (Akıncı, 2002: 223). Çok hızlı değişen ve çoğunlukla yoğun bir rekabet yaşanan turizm piyasasında otel çalışanlarının performanslarına olan güven otel işletmesinin devamlılığı açısından önemlidir (Zopitas vd., 2014: 129). İşletme ve yöneticilerinin kabul etmesi gereken yalın bir gerçek olarak, çalışma eylemi bireyin, işletmelerin ve toplumun üzerinde önemli ekonomik ve sosyal etkilere sahiptir (Özaydın ve Özdemir, 2014: 252). Bu bakımdan iş doyumu ve iş tatmini yüksek olan otel çalışanlarının, tüketicilere daha yüksek düzeyde duygusal emek içinde, ilgili, içten, daha kaliteli hizmet verebileceği ve misafirlerin işletmeden memnun ayrılarak birer bağıı (sadık/sürekli) müşteri duruma getirilmesinde önemli etken olmalarının işletme için ne anlam taşıdığının iyi analiz edilmesi gerekmektedir. Günümüzde artık girişimcinin işletmenin sermayesini koymuş olması, ona işletmenin herşeyine sahip olma anlamında yeterli değildir. Bu bakımdan işletmelerin sahibi, yöneticileri ya da pazarlama sorumluları olmamakta, işletme markasını temsil eden ve tüketici ile her karşılaşma anında kurumu temsil eden kişiler olmaktadır (Doyle, 2004). Otel işletmelerinin hizmet kalitesi, ilke olarak tüketiciler tarafından değerlendirilmesine karşın, hizmeti sunanlar tarafından oluşturulduğu ve hizmeti sunanların sadece hizmeti dağıtan ve meydana getirenler olarak değil, aynı zamanda tüketicilerin gözünde doğrudan işletme ile bir bütün olarak değerlendirmesi bakımından önemlidir (Kandampully ve $\mathrm{Hu}, 2007$ : 436). Bu nedenle turizm işletmelerinin kendi çalışanlarının temel motivasyonlarını olumlu ya da olumsuz yönde etkileyen faktörleri belirleyerek onların daha olumlu koşullarda ve daha üretken olarak çalışmalarını sağlayabilmektedir. Çalışmanın temel amacı da, bu faktörlerin belirlenmesi ile konuya ilişkin literatüre ve iş yaşamına katkı sağlamaktır.

\section{Literatür Taraması}

Çalışanların yaptıkları işe ilişkin bir deyim olarak iş tatmini, kişinin yaptığı işini olumlu, kendisine keyif veren bir duygu olarak değerlendirmesinin bir sonucu olarak tanımlanmaktadır (Locke 1969, Lu ve Gürsoy 2016: 212). Amponsah vd. (2014) iş tatminini "bir bireyin yapmakta olduğu işini bilişsel (kavramsal) ya da duygusal olarak değerlendirilmesi" olarak tanımlar. Diğer bir deyimle iş tatmini; çalışan kişinin kendi 
işinin değişik yönleri hakkındaki düşünce ve duygularını kapsar. İş tatmini genel yaklaşım ve bireysel yaklaşım olmak üzere iki boyutta değerlendirilmektedir. Genel yaklaşımda, iş tatmini yapılan işin olumlu ya da olumsuz olarak bütünsel olarak değerlendirilmesidir. Tek boyutlu yaklaşım olan kişisel boyutta ise, iş tatmini "yapılan işin yükselme, ücret, çalışma arkadaşları ve yöneticiler gibi özel yönlerinin kişisel olarak değerlendirilmesidir" (Amponsah vd., 2016). Bu tanımlara bağlı olarak, Davis (1988) yüksek morale sahip çalışanların üretkenliklerinin de pozitif yönde etkileneceğini ve çalışanın iş tatmininin yüksek olmasının kendisini olumlu yönde motive ederek yaptığı işin tamamlanması konusunda daha istekli olacağını belirtmiştir.

Turizm ve ağırlama endüstrisi iş doyumu ve mesleki tükenmiş açısından bazı sorunları bulunan bir sektördür. Dönemsel yoğunlukların oluşturduğu hızlı ve sıkışık çalışma ortamları ve doğrudan insanları memnun etme hedefi olan bir sektör olması nedeni ile bu konuda alanyazında (literatür) yapılmış çok sayıda çalışma vardır. Bunlardan ön plana çıkanlara ve çalışma konularına bakıldığında, iş tatmininin personel devir hızına etkisi konusunda Amponsah vd. (2016); iş ortamındaki sıkıntı ve bıkkınlıkların boş zaman talebine etkisi konusunda Lin vd. (2014); otel işletmelerinde doğrudan müşteri ile temasın en yoğun olduğu bölüm olan önbüro çalışanlarının işe bağlılıkları ve iş tatminleri konusunda Yeh (2014); otel işletmelerinde duygusal zekâ ve duygusal çalışma ortamının iş tatminindeki rolü konusunda Lee ve Ok (2012); ağırlama işletmelerinde örgüt kültürünün çalışma stresi ve yılgınlık (tükenmişlik) üzerine etkileri konusunda Ramarumo (2015); turizm işletmelerinde iş tatmini, duygusal emek ve tükenmişlik ilişkilerinin analizi hakkında (Mengenci, 2015); Havayolu firmalarında uçuş görevlileri arasında mesleki yılgınlık (tükenmişlik) ve soyutlanma'nın geçmişi ve sonuçlarının irdelenmesi konusunda Chen ve Kau (2012); Konaklama işletmelerinde kurumsal sosyal sorumluluk algısının iş doyumu üzerine etkisi konusunda $\mathrm{Avcı}$ ve Akdemir (2014); ağırlama işletmelerinde mutfak çalışanlarının mesleki tükenmişlik duygularında ve iş değiştirme niyetlerinde stress faktörünün rolü konusunda Jung vd. (2012); yine ağırlama işletmelerinde mobbing, mesleki yılgınlık, iş doyumu ve algılanan örgütsel destek konusunda Çivilidağ (2014); otel işletmelerinde mesleki yılgınlık ve iş doyumu ilişkileri konusunda Kılıç vd. (2011); otel işletmelerinde mesleki yılgınlığın azaltılması ve iş doyumunun artırılması konusunda çalışanlarının duygusal zekâ ve duygusal işgücü'nün rolü (müşteriye karşı olumlu yaklaşım, güleryüz) konusunda Jung ve Lee (2012) ve otel endüstrisinde stres, iş doyumu ve duygusal yılgınlık konusunda danışman desteğinin rolü konusunda da Karatepe (2010)'nin çalışmaları son yıllarda yapılan ve öne çıkan çalışmalardan bazılarıdır. Bu konuda uluslararası alanda en son ve en önemli çalışmalardan birisi de Pizam ve Neumann'ın 2015 tarihli olan ağırlama endüstrisi çalışanlarının görev özelliklerinin iş doyumu ile mesleki tükenmişlik üzerine etkisi üzerine yapmış oldukları çalışmadır.

Bu çalışmalarda çalışanların iş doyumu ve mesleki tükenmişlikleri (yılgınlıkları) konusunda birçok değişken ve bu değişkenlerin iş doyumu ve mesleki/duygusal tükenmişlik üzerine etkileri belirlenmiştir. Bunlardan önemli olanlarını vurgulamak gerekirse; Pizam ve Neuman (2015) çalışanların görev özelliklerinin iş tatmini konusunda en önemli etken olduğunu, bununla birlikte görev özelliklerinin aynı zamanda mesleki tükenmişlik, diğer bir deyimle duygusal tükenmişlik üzerinde de etkili olduğunu vurgulamıştır. Karatepe (2010) çalışmasında denetimci desteğinin duygusal tükenmişliğin azaltılmasında önemli role sahip olduğunu belirtmiş, Kılıç vd. (2011) ise mesleki tükenmişliğin doğrudan doğruya iş doyumunu olumsuz yönde etkilediğini belirlemişlerdir. Çivilidağ'ın çalışması bu alanda başka değişkenleri de dahil ederek özellikle mobbing, çalışma koşulları, rol belirsizliği, iş yükü ve müşteri ile yoğun temas gibi etkenlerin mesleki tükenmişliğe ve buradan da iş doyumuna etkilerini incelemiştir. Jung vd. (2012)'nin çalışmaları mesleki tükenmişlik düzeyi yükseldikçe personelin işi 
bırakma eğiliminin de yükseldiğini belirlemiştir. Lee ve Ok (2012) çalışmalarında duygusal zekâ, duygusal uyumsuzluk ve duygusal çaba arasındaki ilişkilerin ve bunların iş doyumu üzerindeki etkilerini incelemişlerdir. Buradan, duygusal uyumsuzluğun iş doyumunu ve duygusal tükenmişliği dolaylı olarak etkilediği, buna karşılık aynı faktörün duyarsızlaşmayı da doğrudan etkilediği belirlenmiştir. Bianchi vd. (2014) ise turizm alanı dışında yapmış oldukları çalışmada tükenmişliğin sadece işyeri ve çalışma ortamından kaynaklanmayabileceği, kişinin özel yaşamındaki stress yaratan koşullarının da tükenmişliği tetikleyebileceğini belirtmişlerdir. Bu nedenle yazarlar, tükenmişlik konusunda çalışmaların, işyeri özellikli genel yaklaşımlardan ziyade, çok boyutlu ve birden fazla alanla ilgili olarak yapılması gereğini vurgulamışlardır. Amponsah vd. (2016) ise stress faktörünün iş tatmini üzerinde etkisini inceledikleri çalışmada mesleki tükenmişlik faktörünün doğrudan iş doyumunu etkilemediğini, ancak stress faktörünün mesleki tükenmişliği pozitif yönde etkilemesi ile aracı bir değişken rolü oynadığını, bunun da işi bırakma eğilimlerini artırdığını belirlemişlerdir.

İş tatmini, toplumda fiziksel ve ruhsal açıdan sağlıklı ve mutlu bireylerin oluşmasına katkı sağladığı gibi işletmelerde işe ve işyerine bağlıı̆̆ını artırmakta, işgücü devir hızı oranının azalmasını ve örgütsel işgücü başarımının sağlanması için de uygun ortam oluşturmaktadır (Akıncı, 2002: 23). Kaya (2010) tarafından otel işletmelerinde çalışanlar üzerinde yapılan bir araştırmada otel çalışanlarının iş tatminini etkileyen en önemli faktörün başta amirler ile işin niteliği, ücret ve diğer faktörlerin olduğu saptanmış ve iş doyumu sağlandıkça işten ayrılma eğiliminin azaldığı bulunmuştur (Kaya, 2010: 231).

Yine konuya ilişkin diğer çalışmalar arasında Tütüncü ve Kozak (2007), turizm sektöründe kalitenin çalışanlarca meydana getirilmesi tüketicilerin öznel (subjektif) değerlendirmeleri ile gerçekleşmesinden dolayı çalışanların tatmininin ölçülmesinin önemli olduğunu vurgulamaktadırlar.

Iş Doyumu ve Mesleki Tükenmişlik arasında yakın bir ilişki olduğu çeşitli çalışmalarda (Lu ve Gürsoy, 2016; Okray ve Abatay, 2015; Üngüren vd., 2010) incelenmiştir. Tükenmişlik, yüz yüze yapılan işlerde çalışanlar arasında duygusal tükenme, duyarsızlaşma ve kişisel başarı azalması hissi olarak tanımlanmaktadır (Leiter ve Maslach, 1988: 297). Tükenmişlik bir süreç olarak aşırı kronik iş taleplerinin sonucunda bireylerin duygusal kaynaklarını bitirmesi ve tükenmesi olarak da kabul edilmektedir. Bu nedenle iş doyumu ile tükenmişlik arasındaki ilişkilerin daha ayrıntılı incelenmesi yararlı olacaktır.

\section{Araştırmanın Yöntemi}

\section{1. Çalışmanın Amacı, Problemi ve Araştırma Soruları}

Bu çalışmanın amacı, beş yıldızlı otel işletmeleri çalışanlarının iş doyumlarının belirlenmesi ve otel çalışanlarının iş doyumlarının tükenmişlik üzerine etkisinin ölçülmesidir. İş doyumu, bu çalışma kapsamında kısaca "çalışanların yaptıkları işinden duydukları memnuniyet" olarak açıklanmaktadır. Çalışanların işinden memnuniyet duyabilmeleri için de işin iç ve dış koşullarının çalışanlarda olumsuz durumlar oluşturmaması beklenir. Çalışanların yaptığı işin kendisi ve işletme ile ilgili pozitif duygular içinde olması onların yüksek iş doyumu yaşadığını ifade etmektedir. Tükenmişlik ise, kısaca çalışanların yaptıkları işe ilişkin heves ve isteklerinin en alt düzeylere düşmesi ve duyarsızlığı artmış olması olarak kabul edilmiştir. 
Bu nedenle çalışmanın problemi şu şekilde oluşturulmuştur; "Turizm sektöründe ve özellikle otel işletmelerinde çalışanların iş verimliliğini etkileyen en önemli faktörlerden biri olarak "iş doyumu", çalışanların mesleki tükenmişliklerinden önemli ölçüde etkilenmektedir. Bu nedenle Mesleki ve/veya duygusal tükenmişlik ile iş doyumu arasındaki ilişkilerin incelenmesi gerekir".

Araştırma problemine uygun olarak, çalışmanın "iş doyumu" ile ilgili oluşturulmuş olan iki temel araştırma sorusu aşağıdaki şekildedir;

a. Otel çalışanları için iş doyumu ne düzeydedir?

b. Çalışanların iş doyumu ve tükenmişlikleri arasında ilişki var mıdır? Eğer bir ilişki var ise bu ne yönlü bir ilişkidir?

Otel çalışanlarının müşterilerle yüz yüze iş görme biçimi ve otelcilik mesleğinin yapısal özelliği gereği oluşan zorlu koşullar çalışanlarda işine karşı ilgisizlik, bıkkınlık ve dolayısı ile çalışanın oteldeki işinde duyarsızlaşma, duygusal tükenme ve kişisel başarısının azalması gibi sonuçlar meydana getiren ve tükenmişlik sendromu ile açıklanan olumsuz psikolojik bir durum meydana getirebilmektedir. Bu durum otel çalışanlarının verimliliğinin düşmesine bağlı olarak otel işletmelerinin veriminin düşmesi gibi bağlantılı diğer önemli bir sonucu da meydana getirmektedir.

Bu nedenle çalışmanın diğer araştırma soruları aşağıdaki şekilde oluşturulmuştur;

1. Otel çalışanları tükenmişlik yaşamakta mıdırlar? Tükenmişlik yaşanıyor ise bu hangi boyutlardadır?

2. Demografik özelliklere göre tükenmişlik durumu arasında anlamlı bir farklılık var mıdır? Bu farklılık var ise hangi düzeyde ve hangi değişkenlere göre oluşmaktadır?

$\mathrm{Bu}$ nedenler çalışanların işinden doyumunun sağlanması, sağlanan doyum aracılığı ile tükenmişliğin önüne geçilmesi sağlanabilir. Bu durumun sonucu olarak otel çalışanların verimliliği otel işletmesinin verimliliğinde kaldıraç etkisi yaparak, çalışanların olduğu kadar otel işletmesinin başarının da artırabilir. Bu nedenlerle çalışmanın diğer önemli bir boyutu olarak da aşağıdaki sorular oluşturulmuştur;

1. Otel çalışanlarında iş doyumu ile genel tükenmişlikleri arasında bir ilişki var mıdır?

2. Otel çalışanlarında iş doyumu ile tükenmişlik sendromunun alt boyutları arasında bir ilişki var mıdır? Varsa bu ilişki hangi yöndedir?

3. Otel çalışanlarının iş doyumu ve tükenmişlikleri arasında çalışanların iç ve dış doyumlarına göre bir farklılık var mıdır?

4. Otel çalışanlarında iç ve dış doyum faktörlerinin otel çalışanlarının tükenmişlikleri üzerinde bir etkisi var mıdır? Varsa ne düzeydedir?

\section{Şekil 1: Araştırma Modeli}

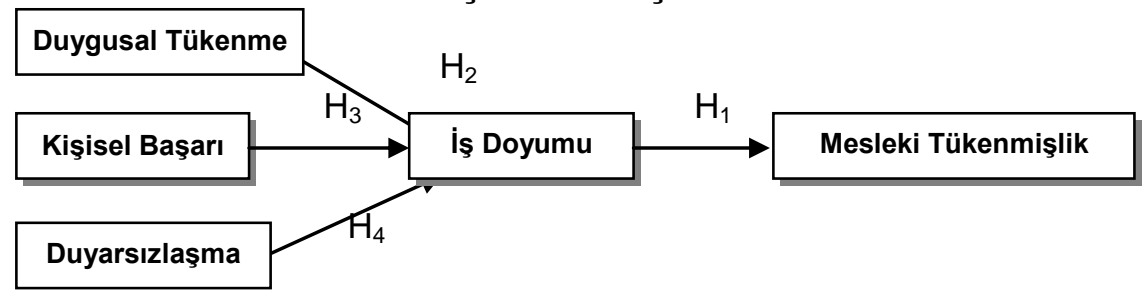


Çalışmanın temel modeli Şekil.1'de gösterilmiştir. Bu model kapsamında çalışma sorularına ve konunun literatür geçmişine bağlı olarak çalışma için şu hipotezler geliştirilmiştir;

$\mathbf{H}_{1}$ : İş doyumunun tükenmişlik üzerinde pozitif bir etkisi vardır. Diğer bir deyimle artan iş doyumu tükenmişlik düzeyini azaltıcı bir etkiye sahiptir.

$\mathbf{H}_{2}$ : Duygusal tükenme ile iş doyumu arasında negatif yönde bir ilişki vardır

$\mathbf{H}_{3}$ : Kişisel başarı ile iş doyumu arasında pozitif yönlü ilişki mevcuttur.

$\mathrm{H}_{4}$ : Duyarsızlaşma ile iş doyumu arasında negatif yönlü ilişki vardır. Diğer alt hipotezler de aşağıdaki şekilde oluşturulmuştur.

$\mathbf{H}_{5}$ : İç doyum ve dış doyum değişkenleri bakımından çalışanların cinsiyetlerine göre anlamlı bir farklılık vardır.

$\mathbf{H}_{6}$ : Evli ve bekâr çalışanların doyum düzeyleri arasında anlamlı farklııı vardır.

$\mathbf{H}_{7}$ : Doyum (genel) değişkeni bakımından çalışılan bölümler arasında farklılık vardır.

$\mathbf{H}_{8}$ : Dış doyum değişkeni bakımından çalışma saatleri arasında farklılık mevcuttur.

\subsection{Araştırmanın Örneklemi ve Veri Toplama Aracı}

"Açıklayıcı (explanatory)" bir yaklaşım şeklinde tasarlanan ve sayısal (niceliksel) bir araştırma niteliğinde olan bu çalışmada, alan araştırması (survey/tarama) yöntemi uygulanmıştır. Araştırmada veri toplama aracı olarak, içeriği daha önce açıklanan ölçeklerden (Minnesota ve Maslach) oluşan anket formu kullanılmış, örneklem belirleme yöntemi olarak da "basit tesadüfi örnekleme" uygulanmıştır.

Araştırmada Kuzey Kıbrıs genelinde beş yıldızlı otel çalışanları hedef kitle olarak seçilmiştir ve araştırmanın ana kütlesini(evren) otel işletmelerinin çeşitli bölümlerinden çalışanlar oluşturmaktadır. Araştırmanın yapıldığı dönemde K.K.T.C.'deki beş yıldızlı otel işletmelerindeki istihdam yaklaşık 3450 kişidir (Besim vd. 2015; 107) ve bu rakama göre örneklem sayısı, \% 95 güven aralığında, \% 5 örneklem hatası ile en az 234 kişi olarak bulunmuştur. Dağıtılan anket formalarından geriye dönen ve kullanılabilir nitelikteki 261 anket formu, 234 kişi olarak bulunan örneklem hacminden fazla sayıda olması nedeniyle değerlendirmeye alınmıştır. Araştırma 2014-2015 yıllarını kapsamaktadır.

Araştırmanın veri toplama aracının oluşturulmasında, Minnesota Doyum Ölçeği ve Maslach Tükenmişlik Ölçeği'nden yararlanılarak oluşturulan anket formları kullanılmıştır. Toplam 20 ifadeden oluşan standart ölçeğe demografik değişkenler eklenmiştir. Ölçeğin soru şekli olumlu şekilde yapılandırılmış ve deneklerin yanıtları 5'li Likert ölçeğinden oluşan her bir soru ifadesi için "memnuniyef" derecelerine göre yanıt verilmesi istenmiştir. En yüksek ve güçlü memnuniyet (5), en düşük ve zayıf memnuniyet de (1) olarak sıralanmıştır. Elde edilen veriler ilgili istatistiksel analiz programı aracılığı ile analiz edilerek açıklanmaya çalışılmıştır. Araştırmanın sınılıığı ise, yapılan bölge Kuzey Kıbrıs Cumhuriyeti bölgesindeki 5 yıldızlı otel çalışanları ile sınırlı olmasıdır.

\subsection{Araştırmada Kullanılan Veri Toplama Aracının Güvenirlilik Analizi}

Araştırmada kullanılan Maslach Doyum Ölçeğinin güvenirlilik analizleri Cronbach's Alpha katsayılarının hesaplanmasıyla yapılmıştır. Herhangi bir konuda hazırlanmış olan bir ölçeğin güvenirlilik durumu $0,00 \leq \alpha \leq 0,40$ ise ölçek güvenilir değil, $0,40 \leq \alpha \leq$ 0,60 ise ölçek düşük güvenilir $0,60 \leq \alpha \leq 0,80$ ise oldukça güvenilir, $0,80 \leq \alpha \leq 1,00$ ise ölçek yüksek derecede güvenilir bir ölçektir (Akgül ve Çevik, 2003: 428). Tablo 1'de 
gösterilen Minnesota Doyum ölçeği ve alt boyutlarının Cronbach's alfa kat sayılarının yüksek ve oldukça güvenilir bir ölçek olduğu anlaşılmaktadır.

Tablo 1: Ölçeklerin Güvenirlilik (Cronbach's Alpha a) Test Değerleri

\begin{tabular}{|l|l|c|l|}
\hline \multicolumn{2}{|l|}{} & $\begin{array}{l}\text { Madde } \\
\text { Sayısı }\end{array}$ & $\begin{array}{l}\text { Cronbach's Alpha } \\
\text { Katsayısı }\end{array}$ \\
\hline \multicolumn{2}{|l|}{ Minnesota Doyum Ölçeği ve Alt Boyutlarının Cronbach Alpha Katsayısı } \\
\hline İc Doyum & & 12 & 0,901 \\
\hline Dış Doyum & & 8 & 0,884 \\
\hline Genel Doyum & & 20 & 0,943 \\
\hline
\end{tabular}

Ölçeklerin faktör yapısını belirlemek amacıyla elde edilen verilere varimax rotasyonu temel bileşenler faktör analizi uygulanmıştır. Faktör Analizine uygunluğunun sınanması için Bartlett sınaması ve Kaiser - Mayer - Olkin (KMO) ölçütüne bakılmıştır. Bartlett sınaması bir küresellik sınaması olup, verilerin bir biriyle ilişkili olup olmadığını göstermektedir. Bartlett Sınaması Değeri $=2276,797 ; p=0.000$ olarak hesaplanmıştır. KMO Değeri $=0,908 ; p=0.000$ olarak hesaplanmıştır. Sosyal Bilimler alanındaki araştırmalarında genellikle KMO değerinin 0,60'dan büyük olması örneklem büyüklüğünün yeterli olduğunu göstermektedir. Analiz sonucunda "Açıklanan Toplam Varyans" değeri olarak bulunan 55.152'lık değer de, 40-60 arasında bir değer olduğu için yine sosyal bilimler alanında yeterli kabul edilmektedir (Karagöz, 2016: 880). Hesaplanan istatistiksel değerlere göre verilerin faktör analizi çalışmasına uygun olduğu görülmüştür.

Tablo 2: Doyum Ölçeği ve Alt Boyutlarına Ait Faktör Analizi

\begin{tabular}{|l|r|}
\hline KMO & \multicolumn{1}{|c|}{0.908} \\
\hline Bartlett's Değeri & 2276.797 \\
\hline Bartlett's Sig Değeri & .000 \\
\hline Açıklanan Toplam Varyans & 55,152 \\
\hline
\end{tabular}

Tablo 3: Minnesota Doyum Ölçeğine İlişkin Faktör Analizi

\begin{tabular}{|c|c|c|c|}
\hline Faktörlerin Dağılımı & $\begin{array}{l}\text { Faktör } \\
\text { Yükleri }\end{array}$ & Ort. & Ss. \\
\hline \multicolumn{4}{|l|}{ Faktör 2. Dış Doyum } \\
\hline 5. Şimdiki işimden "yöneticimin ekibindeki kişileri idare tarzı" bakımından & 0.871 & 3.52 & 1.22 \\
\hline 6. Şimdiki işimden "yöneticimin karar vermedeki yeteneği" bakımından & 0.891 & 3.49 & 1.18 \\
\hline 12. Şimdiki işimden "iş ile ilgili kararların uygulanmaya konması" bakımından & 0.626 & 3.53 & 1.05 \\
\hline 13. Şimdiki işimden "yaptığım iş ve karşılığında aldığım ücret" bakımından & 0.685 & 3.27 & 1.21 \\
\hline 14. Şimdiki işimden "iş içinde terfi olanağımın olması" bakımından & 0.977 & 3.24 & 1.27 \\
\hline $\begin{array}{l}\text { 16. Şimdiki işimden "işimi yaparken kendi yöntemlerimi kullanabilme şansını bana } \\
\text { vermesi" bakımından }\end{array}$ & 0.936 & 3.51 & 1.23 \\
\hline 17. Şimdiki işimden "çalışma şartları" bakımından & 0.516 & 3.54 & 1.11 \\
\hline 18. Şimdiki işimden "çalışma arkadaşlarımın birbirleri ile anlaşmaları" bakımından & 0.586 & 3.66 & 1.16 \\
\hline \multicolumn{4}{|l|}{ Faktör 1. İç Doyum } \\
\hline 1. Şimdiki işimden "beni her zaman memnun etmesi" bakımından & 0.650 & 3,48 & 1.05 \\
\hline 2. Şimdiki işimden "tek başıma çalışma olanağı olması" bakımından & 0.874 & 3,45 & 1.17 \\
\hline 3. Şimdiki işimden "ara sıra değişik şeyler yapabilme şansı" bakımından & 0.821 & 3.59 & 1.12 \\
\hline 4. Şimdiki işimden "toplumda saygın bir kişi olma şansını vermesi" bakımından & 0.706 & 3.51 & 1.25 \\
\hline $\begin{array}{l}\text { 7. Şimdiki işimden "vicdanıma aykırı olmayan şeyler yapabilme şansım olması" } \\
\text { bakımından }\end{array}$ & 0.677 & 3.46 & 1.17 \\
\hline 8. Şimdiki işimden "bana sabit bir iş sağlaması" bakımından & 0.708 & 3.70 & 1.05 \\
\hline
\end{tabular}


Tablo'3 ün Devamı

\begin{tabular}{|l|c|c|c|}
\hline $\begin{array}{l}\text { 9. Şimdiki işimden "başkaları için bir şeyler yapabilme olanağı bana vermesi" } \\
\text { bakımından }\end{array}$ & 0.621 & 3.80 & 1.04 \\
\hline $\begin{array}{l}\text { 10. Şimdiki işimden "kişilere ne yapacaklarını söyleme şansına sahip olma” } \\
\text { bakımından }\end{array}$ & 0.728 & 3.61 & 1.13 \\
\hline $\begin{array}{l}\text { 11. Şimdiki işimden “kendi yeteneklerimi kullanarak bir şeyler yapabilme şansı } \\
\text { olması" bakımından }\end{array}$ & 0.459 & 3.71 & 1.16 \\
\hline $\begin{array}{l}\text { 15. Şimdiki işimden "kendi kararlarımı uygulama serbestliğini bana vermesi" } \\
\text { bakımından }\end{array}$ & 0.351 & 3.33 & 1.24 \\
\hline 19. Şimdiki işimden "yaptığım iyi bir iş karşılığında takdir edilme” bakımından & 0.392 & 3.40 & 1.26 \\
\hline 20. Şimdiki işimden "yaptığım iş karşılığında duyduğum başarı hissi” bakımından & 0.500 & 3.75 & 1.23 \\
\hline
\end{tabular}

İş doyumu ile ilgili toplanan verinin yapısına uygun olan faktör sayısını belirlemek amacıyla ilgili ifadeler açıklayıcı faktör analizi ile incelenmiştir. Faktör analizi sonucunda "iç doyumu" (1. Faktör) ile ilgili ifadelerin literatürde olduğu biçimde Soru 1, 2, 3, 4, 7, 8, 9, 10, 11, 15, 19, 20'den oluştuğu, "dış doyumu" (2.faktör) ile ilgili ifadelerin de soru $5,6,12,13,14,16,17$ ve 18'den oluştuğu görülmüştür. Ölçekteki tüm sorular ise "genel doyumu" oluşturmaktadır. Analiz sonuçlarına göre, her iki faktörde değişkenliği \% 55,15 oranında açıklayan (Tablo 2) uygun bir modele ulaşılmıştır.

\section{Bulgular ve Değgerlendirme}

Araştırmaya katılanların genel profili ve demografik özelliklerine ilişkin bilgiler aşağıdaki tabloda yer almaktadır.

Tablo 4: Araştırmaya Katılan Otel Çalışanlarının Profili

\begin{tabular}{|c|c|c|c|c|c|c|c|c|}
\hline Cinsiyet & $\mathbf{N}$ & $\%$ & Medeni Durum & $\mathbf{N}$ & $\%$ & $\begin{array}{l}\text { Sektördeki } \\
\text { Çalışma Yılı }\end{array}$ & $\mathbf{N}$ & $\%$ \\
\hline Kadın & 81 & 31.9 & Evli & 92 & 60,7 & Bir yıldan az & 20 & 7,9 \\
\hline Erkek & 173 & 66.3 & Bekâr & 156 & 35,8 & $1-3 y ı l$ & 66 & 26,1 \\
\hline Toplam & 254 & 100 & Toplam & 248 & 100 & $4-5 \mathrm{yll}$ & 44 & 17,4 \\
\hline Yaş & $\mathbf{N}$ & $\%$ & Eğitim & $\mathbf{N}$ & $\%$ & $6-10 \mathrm{yll}$ & 73 & 28,8 \\
\hline $18-25$ & 82 & 34,0 & İlköğretim & 27 & 10,4 & $11-15 \mathrm{yll}$ & 37 & 14,6 \\
\hline $26-35$ yaş & 123 & 51,0 & Ortaöğretim & 33 & 12,7 & 15 yıldan fazla & 13 & 5,1 \\
\hline $36-45$ yaş & 30 & 12,4 & lise & 111 & 42,7 & Toplam & 259 & 100 \\
\hline $\begin{array}{l}46-55 \text { ve üzeri } \\
\text { yaş }\end{array}$ & 6 & 2,5 & Ön Lisans & 36 & 13,8 & Çalışılan Süre & $\mathbf{N}$ & $\%$ \\
\hline Toplam & 241 & 100 & Lisans & 53 & 20,4 & 8 saaten az & 9 & 3,5 \\
\hline $\begin{array}{l}\text { Çalışılan } \\
\text { Bölüm }\end{array}$ & $\mathbf{N}$ & $\%$ & Toplam & 260 & 100 & 8 saat & 152 & 58,7 \\
\hline Yiyecek İçecek & 100 & 46,6 & $\begin{array}{l}\text { Turizm Eğitimi } \\
\text { Türü }\end{array}$ & $\mathbf{N}$ & $\%$ & 9-10 saat & 61 & 23,6 \\
\hline Önbüro & 12 & 5,2 & Turizm Lisans & 27 & 12,0 & $11-12$ saat & 32 & 12,4 \\
\hline Kat Hizm. & 65 & 28,0 & Turizm Önlisans & 22 & 9,8 & 12 saatan fazla & 5 & 1,9 \\
\hline Satış/paz. & 6 & 2,6 & Turizm Lisesi & 37 & 16,4 & Toplam & 259 & 100 \\
\hline İnsan Kyn. & 5 & 2,2 & Turizm Sertifikası & 26 & 11,6 & Aylık Gelir (TI) & $\mathbf{N}$ & $\%$ \\
\hline Mutfak & 28 & 12,1 & Meslekiçi Eğitim & 74 & 32,9 & $1000-1500$ & 61 & 25,1 \\
\hline Güvenlik & 8 & 3,4 & Diğer & 39 & 17,3 & $1501-2000$ & 92 & 37,9 \\
\hline Toplam & 232 & 100 & Toplam & 225 & 100 & $2001-2500$ & 69 & 28,4 \\
\hline $\begin{array}{l}\text { Işletmedeki } \\
\text { Görevi }\end{array}$ & $\mathbf{N}$ & $\%$ & & & & $2501-3500$ & 21 & 8,6 \\
\hline Böl.Md./yrd. & 13 & 5,0 & & & & Toplam & 243 & 100 \\
\hline Bölüm şefi & 44 & 17,1 & & & & & & \\
\hline Bölüm çalışanı & 201 & 77,9 & & & & & & \\
\hline Toplam & 258 & 100 & & & & & & \\
\hline
\end{tabular}


Araştırmaya katılanların 81'i (\% 31) kadın, 173'ü (\% 66.3) erkek çalışanlardan oluşmaktadır. Medeni durumlarına bakıldığında ise \% 60,7'i evlilerden (92 kişi) \% 35,8'i bekârlardan (156 kişi) oluşmaktadır. Araştırmaya katılan çalışanların yarıdan fazlası evlilerden oluşmaktadır. Yaşları itibari ile değerlendirildiğinde çalışanların \% 34,0'ü (82 kişi),18-25, \% 51,0’i (123 kişi) 26-35 yaş aralığında olanlardır. Bu sonuçla, çalışanların çoğu 35 yaşının altındaki kişilerden oluştuğu görülmektedir. Katılımcılar eğitim durumlarına göre incelendiklerinde ise \% 23,1'i ilk ve orta öğrenim, \% 42,7'si lise ve \% 20,4 'ü lisans öğrenimine sahip olduğu görülmektedir. Araştırmaya katılan çalışanların turizm eğitimi alıp almadığını belirlemek amacıyla sorulan soru karşılığında çalışanların büyük çoğunluğun turizm eğitimi aldığı ve meslek içi eğitim (\% 34,3) de aldıkları görülmektedir. Sektörde çalışma yıllarına bakıldığında ise araştırmaya katılanların çoğunluğu, \% 28,8'i 6-10 yıldır, \% 50'den fazlasının 6 yıldan daha az olduğu ve uzun süreli olarak, 11 ve daha fazla yıl bu sektörde çalışanların oranı ise sadece $\% 5,1$ oranında olduğu görülmüştür. Çalışanların oteldeki bölümleri ve oranları sırasıyla \% 46,6 yiyecek-içecek; \% 28,0 kat hizmetleri; \% 12,1 mutfak; \% 5,2 ön büro bölümlerinde çalışmakta oldukları görülmektedir. Araştırmaya katılan çalışanların \% 77,9'u bölüm çalışanı, diğerleri bölüm şefi ve müdür ve yardımcısı konumundadır. Elde edilen aylık gelir değişkeni bakımından değerlendirildiğinde ise çalışanların \% 25,1'i 1000-1500; \% 37,9'u 1501-2000; \% 28,4'ü 2001-2500 Türk Lirası ve diğerlerinin bu miktarın üzerinde ücret aldıkları görülmektedir. Türkiye'deki otellerde aynı mevkideki çalışanlar ile kıyaslandığında Kuzey Kıbrıs'taki otellerde çalışanların biraz daha fazla ücret aldığı görülmektedir.

\section{Tablo 5: Araştırmaya Katılanların Mesleki Doyum Düzeyleri}

\begin{tabular}{|c|c|c|}
\hline Minnesota Ölçeği ve Alt Boyutları & \multirow{2}{*}{$\begin{array}{l}\text { Ort. } \\
3.59 \\
\end{array}$} & \multirow{2}{*}{$\begin{array}{l}\text { S. S. } \\
0,80\end{array}$} \\
\hline iç Doyum & & \\
\hline Dış Doyum & 3.49 & 0,86 \\
\hline Genel doyum & 3.52 & 0,81 \\
\hline
\end{tabular}

Tablo 5'te araştırmaya katılanların doyumlarına ilişkin puan düzeyleri gösterilmiştir. Buna göre ortalama puanlar iç doyum için $3,59 \pm 0,80$, dış doyum için $3,49 \pm 0,86$ ve geneli için ise $3,52 \pm 0,81$ şeklinde ortaya çıkmıştır. Otel işletmelerinde çalışanların doyum düzeylerinin iyi düzeyde olduğu söylenebilir.

Tablo 6: Otel Çalışanlarında Tükenmişlik ve Doyum, İç Doyum, Dış Doyum Boyutlarına İlişkin Çoklu Regresyon Analizi Sonuçları

\begin{tabular}{|l|c|c|l|l|l|}
\hline Değişken & \multicolumn{1}{|l|}{ B } & Standart Hata B & $\boldsymbol{\beta}$ & $\mathbf{t}$ & $\mathbf{P}(\mathbf{s i g})$ \\
\hline Sabit & 3.134 & 0.191 & & 16.437 & 0.000 \\
\hline Genel Doyum & -0.030 & 0.017 & -0.970 & -2.188 & 0.030 \\
\hline İç Doyum & 0.049 & 0.019 & 0.938 & 25.95 & 0.011 \\
\hline Dış Doyum & -0.006 & 0.009 & -0.108 & -0.637 & 0.525 Önemsiz \\
\hline
\end{tabular}

$R=0.321, R^{2}=0.103, F_{4,132}=5.041, p=0.002$

Tablo 6'da çoklu regresyon tablosunda görüldüğü üzere otel çalışanlarının iş doyumu ve iş doyumunun alt boyutlarının otel çalışanların tükenmişlikleri üzerindeki etkisini; "Tükenmişlik = $3.134-0.030$ x Genel Doyum + 0.049 x lç Doyum" şeklinde formüle etmek mümkündür. Bu sonuçlar itibari ile doyumun tükenmişlik üzerine etkisinin olduğu sonucuna varılmıştır. Bu sonuca göre $\mathbf{H}_{1}$ : "Iş doyumunun tükenmişlik üzerinde etkisi vardır" hipotezi desteklenmektedir. Bununla birlikte tükenmişliğe etki eden bu faktörlerle yeteri kadar açıklanamadığı sonucuna varılmıştır. Konunun daha 
açık anlaşılır olması için doyum ve tükenmişlik arasında korelasyon kurulmuş ve Tablo 7'deki korelasyon matrisinde açıklanmıştır.

Tablo 7: Otel Çalışanlarının Doyum ve Doyum Alt Boyutları ile Tükenmişlik ve Alt Boyutları Arasındaki Korelasyon Analizi

\begin{tabular}{|l|c|c|c|}
\hline & İç Doyum & $\begin{array}{l}\text { Dış } \\
\text { Doyum }\end{array}$ & Genel Doyum \\
\hline Duygusal Tükenme & -0.387 & $-0.443^{\text {* }}$ & -0.419 \\
\hline Kişisel başarı & 0.414 & $0.333^{\text {" }}$ & 0.424 \\
\hline Duyarsızlaşma & -0.176 & -0.181 & -0.178 \\
\hline
\end{tabular}

** Korelasyon 0.01 düzeyinde anlamlıdır.

* Korelasyon 0.05 düzeyinde anlamlıdır.

Tablo 7'de Minnesota Doyum Ölçeği alt boyutları ile Maslach Tükenmişlik ölçeğinin alt boyutlarına ilişkin korelasyon analizi sonuçları verilmiştir. Bu sonuçlara göre iç doyum, dış doyum ve genel doyum ile duygusal tükenme arasında negatif bir ilişkinin olduğu görülmektedir. Doyum artıkça duygusal tükenme azalmaktadır. Aynı biçimde genel doyum ve ölçeğin alt boyutları ile duyarsızlaşma arasında da negatif yönlü bir ilişki olduğu saptanmıştır. Doyum ölçeği ve alt ölçek boyutlarında ise pozitif yönlü bir ilişkinin olduğu yukarıdaki sonuçlardan anlaşılmaktadır. Sonuç olarak, çalışanların işinden elde ettikleri doyum kişisel başarılarının da artmasını, işinden elde ettikleri doyumsuzluk ise duyarsızlaşma ve duygusal tükenmelerinin artmasına neden olmaktadır. İç doyum ve duygusal tükenmişlik korelasyonu negatif olarak $(r=-0,387, p$ $<0,05)$, iç doyum ve duyarsızlaşma korelasyonu $(r=-0.176, p<0.05)$, İç doyum ile kişisel başarı korelasyonu pozitif olarak $(r=0.414, p<0.05)$ gerçekleşmiştir. Dış doyum ile duygusal tükenme korelasyonu $(r=-0.443, p<0.05)$, Dış doyum ile kişisel başarı korelasyonu pozitif olarak $(r=0.333, p<0.05)$ saptanmıştır. Genel doyum ile duygusal tükenme negatif biçimde $(r=-0.419, p<0.05)$, Genel doyum ile duyarsızlaşma korelasyonu aynı biçimde negatif olarak $(r=-0.178, p<0.05)$ ve genel doyum ile kişisel başarı pozitif olarak $(r=0.424, p<0.05)$ gözlemlenmiştir. Bu sonuçlara göre, $\mathrm{H}_{2}$ : "Duygusal tükenme ile doyum arasında ters yönde bir ilişki vardır", $\mathrm{H}_{3}$ : "Kişisel başarı ile doyum arasında aynı yönlü ilişki mevcuttur" ve $\mathrm{H}_{4}$ : "Duyarsızlaşma ile doyum arasında negatif yönlü ilişki vardır" hipotezleri desteklenmektedir.

Tablo 8: Otel Çalışanlarının Cinsiyeti ve İş Doyumları Arasındaki Farklılığa Yönelik t Testi Sonuçları

\begin{tabular}{|c|c|c|c|c|c|c|}
\hline $\begin{array}{l}\text { Bağımlı } \\
\text { Değişken }\end{array}$ & Cinsiyeti & $\mathbf{n}$ & Ort. & SS & $\mathbf{t}$ & $\mathbf{p}$ \\
\hline \multirow{2}{*}{ İç Doyum } & Kadın & 59 & 3.67 & 0.78 & \multirow[b]{2}{*}{0.949} & \multirow{2}{*}{0.344} \\
\hline & Erkek & 134 & 3.55 & 0.81 & & \\
\hline \multirow{2}{*}{ Dış Doyum } & Kadın & 62 & 3.60 & 0.75 & \multirow{2}{*}{1.181} & \multirow{2}{*}{0.239} \\
\hline & Erkek & 138 & 3.44 & 0.91 & & \\
\hline \multirow{2}{*}{ Genel Doyum } & Kadın & 53 & 3.65 & 0.75 & \multirow{2}{*}{1.342} & \multirow{2}{*}{0.181} \\
\hline & Erkek & 125 & 3.47 & 0.83 & & \\
\hline
\end{tabular}

Tablo 8'de görüldüğü gibi, otel çalışanlarının cinsiyetleriyle iç doyumları arasında anlamlı bir farklılık çıkmamıştır $(t=0.949 ; p=0,344>0,05)$. Dış Doyumlarına bakıldığında da yine anlamlı bir farklılık görülmemektedir ( $t=1.181 ; p=0,239>0,05)$. Benzer şekilde genel doyum değişkeni bakımından bayan ve erkekler arasında anlamlı bir farklılık bulunmamıştır $(p=0.181>0.05)$. Bu sonuçlara göre $\mathrm{H}_{5}$ : "İç doyum ve dış 
doyum değişkenleri bakımından erkek ve bayanlar arasında anlamlı bir farklııı vardır" hipotezleri desteklenmemektedir.

Tablo 9: Otel Çalışanlarının Medeni halleri ve İş Doyumları Arasındaki Farklıığa Yönelik (t) Testi Sonuçları

\begin{tabular}{|c|c|c|c|c|c|c|}
\hline Bağımlı Değişken & Medeni Hali & $\mathbf{n}$ & Ort. & SS & $\mathbf{t}$ & $\mathbf{p}$ \\
\hline \multirow{2}{*}{ İç Doyum } & Bekar & 122 & 3.57 & 0.82 & \multirow{2}{*}{-0.717} & \multirow{2}{*}{0.476} \\
\hline & Evli & 67 & 3.65 & 0.73 & & \\
\hline \multirow{2}{*}{ Dış Doyum } & Bekar & 125 & 3.50 & 0.87 & \multirow{2}{*}{0.127} & \multirow{2}{*}{0.899} \\
\hline & Evli & 71 & 3.48 & 0.85 & & \\
\hline \multirow{2}{*}{ Genel Doyum } & Bekar & 111 & 3.50 & 0.83 & \multirow{2}{*}{-0.678} & \multirow{2}{*}{0.499} \\
\hline & Evli & 63 & 3.58 & 0.76 & & \\
\hline
\end{tabular}

Tablo 9'da otel çalışanlarının medeni durumları ile iç doyumları arasında anlamlı bir farklılık olmadığı gözlemlenmektedir $(t=-0.717 ; p=0,476>0,05)$. Bununla birlikte, ortalamalara bakıldığında evli çalışanlar $(\mathrm{O} . \mathrm{S} .=3,65)$ bekâr $(\mathrm{O} . \mathrm{S} .=3.57$ ) çalışanlara göre daha fazla iç doyum elde ettikleri buna karşın bekârların evlilere göre daha az iç doyum yaşadıkları söylenebilir. Dış Doyumlarına bakıldığında da anlamlı bir farklılık görülmemektedir $(t=0.127 ; p=0,899>0,05)$. Evli ve bekârlar yaklaşık aynı düzeyde dış doyum yaşamaktadırlar. Otel çalışanlarının medeni durumları ile genel doyum durumlarına arasında da anlamlı bir farklılık çıkmamıştır. Bu sonuçlara göre, $\mathrm{H}_{6}$ : "Evli ve bekâr çalışanların doyum düzeyleri arasında anlamlı farklılık vardır" hipotezi desteklenmemektedir.

Tablo 10: Otel Çalışanların Çalıştıkları Bölüm (Departman) ile İş Doyumları Arasındaki Farklılığa Yönelik Tekyönlü Varyans Analizi (Anova) Sonuçları

\begin{tabular}{|c|c|c|c|c|c|}
\hline & $\begin{array}{l}\text { Çalışılan } \\
\text { Bölüm }\end{array}$ & Ort. & SS & $\mathbf{F}$ & p \\
\hline \multirow{7}{*}{ İç Doyum } & $\begin{array}{l}\text { Yiyecek ve } \\
\text { İçecek }\end{array}$ & 3.67 & 0.71 & \multirow{7}{*}{2.726} & \multirow{7}{*}{0.015} \\
\hline & Ön Büro & 3.97 & 0.56 & & \\
\hline & Kat Hizmetleri & 3.33 & 0.88 & & \\
\hline & Satış Pazarlama & 3.49 & 0.88 & & \\
\hline & İnsan Kaynakları & 3.91 & 0.69 & & \\
\hline & Mutfak & 3.15 & 0.81 & & \\
\hline & Güvenlik & 3.99 & 0.78 & & \\
\hline \multirow{7}{*}{ Dış doyum } & $\begin{array}{l}\text { Yiyecek ve } \\
\text { İcecek }\end{array}$ & 3.53 & 0.86 & \multirow{7}{*}{1.693} & \multirow{7}{*}{0.125} \\
\hline & Ön Büro & 3.90 & 0.87 & & \\
\hline & Kat Hizmetleri & 3.33 & 0.84 & & \\
\hline & Satış Pazarlama & 3.18 & 0.64 & & \\
\hline & İnsan Kaynakları & 3.45 & 0.65 & & \\
\hline & Mutfak & 3.08 & 0.90 & & \\
\hline & Güvenlik & 3.98 & 0.92 & & \\
\hline \multirow{7}{*}{ Genel Doyum } & $\begin{array}{l}\text { Yiyecek ve } \\
\text { İçecek }\end{array}$ & 3.60 & 0.76 & \multirow{7}{*}{2.573} & \multirow{7}{*}{0.021} \\
\hline & Ön Büro & 4.00 & 0.74 & & \\
\hline & Kat Hizmetleri & 3.28 & 3.83 & & \\
\hline & Satış Pazarlama & 3.27 & 3.69 & & \\
\hline & İnsan Kaynakları & 3.81 & 3.61 & & \\
\hline & Mutfak & 3.04 & 0.80 & & \\
\hline & Güvenlik & 3.94 & 0.86 & & \\
\hline
\end{tabular}


Tablo 10'daki sonuçlar incelendiğinde otel çalışanlarının çalıştıkları bölüm ile iç doyum ve genel doyum arasında anlamlı farklılık (iç doyum $p=0.015<0.05$ ve genel doyum $p=0.021<0.05$ ) olduğu görülmektedir. Otel çalışanlarının çalıştıkları bölüm ile dış doyum arasında ise anlamlı bir farklılığın (dış doyum $p=0.125>0.05$ ) olmadığı görülmektedir. Otel çalışanlarının çalıştıkları bölüm ile iç doyum arasındaki farklılığın analizine yönelik yapılan çoklu karşılaştırma test istatistiğinin sonucuna göre "mutfak ile ön büro" ve "mutfak ile güvenlik" bölümleri çalışanları arasında anlamlı bir farkılık olduğu sonucu ortaya çıkmıştır. Bu sonuçlara göre, H7: "Doyum (genel) değişkeni bakımından çalışılan bölümler arasında farkııık vardır" hipotezi desteklenmektedir. Ortalamalara bakıldığında mutfak çalışanları 3.14, ön büro çalışanları 3.97 ve güvenlik çalışanları 3.99 ortalamalara sahip olduğu ve mutfak bölümü çalışanlarının diğerlerine göre en az iç doyum yaşadıkları saptanmıştır. Bu durumun tersi olarak güvenlik ve ön büro çalışanları en yüksek iç doyum yaşamaktadırlar. Bölüm çalışanları genel doyumlarına göre değerlendirildiğinde ise yine mutfak ve ön büro çalışanları arasında anlamlı farklılık olduğu ve aynı şekilde mutfak çalışanlarının en az, ön büro ve güvenlik çalışanlarının en yüksek düzeyde genel doyum yaşadıkları saptanmıştır.

Tablo 11: Çalışanların Çalışma Saati ve İş Doyumları Arasındaki Farklılığa Ait Tekyönlü Varyans Analizi (Anova) Sonuçları

\begin{tabular}{|c|c|c|c|c|c|}
\hline & Çalışma Saati & Ort. & SS & $\mathbf{F}$ & $\mathbf{p}$ \\
\hline \multirow{5}{*}{ İç Doyum } & 8 sa. az & 3.38 & 0.59 & \multirow{5}{*}{1.943} & \multirow{5}{*}{0,105} \\
\hline & $8 \mathrm{sa}$. & 3.62 & 0.80 & & \\
\hline & $8-10 \mathrm{sa}$ & 3.75 & 0.77 & & \\
\hline & $10-12$ & 3.30 & 0.81 & & \\
\hline & $12+$ & 3.13 & 0.93 & & \\
\hline \multirow{5}{*}{ Dış doyum } & 8 sa. az & 3.40 & 0.61 & \multirow{5}{*}{2.957} & \multirow{5}{*}{0.021} \\
\hline & $8 \mathrm{sa}$. & 3.57 & 0.83 & & \\
\hline & $8-10 \mathrm{sa}$ & 3.54 & 0.84 & & \\
\hline & $10-12$ & 3.26 & 0.84 & & \\
\hline & $12+$ & 2.38 & 1.37 & & \\
\hline \multirow{5}{*}{ Genel Doyum } & 8 sa. az & 3.39 & 0.59 & \multirow{5}{*}{2.000} & \multirow{5}{*}{0.097} \\
\hline & $8 \mathrm{sa}$. & 3.56 & 0.80 & & \\
\hline & $8-10 \mathrm{sa}$ & 3.67 & 0.77 & & \\
\hline & $10-12$ & 3.27 & 0.81 & & \\
\hline & $12+$ & 2.83 & 1.09 & & \\
\hline
\end{tabular}

Tablo 11'daki sonuçlar incelendiğinde dış doyum faktörü bakımından çalışma süreleri arasında anlamlı farklılık bulunmuştur $(p=0.021<0.05)$ ve bu sonuçla H8: Dış Doyum değişkeni bakımından çalışma saatleri arasında farklılık mevcuttur" hipotezi desteklenmiştir. Farklıı̆̆ın kaynağını belirlemek amacıyla yapılan Duncan çoklu karşılaştırma testi sonucuna göre 12 saatten fazla çalışanlar 12 saatten az çalışanlara göre farklılık göstermektedir. 12 saatten fazla çalışanlar en az doyuma sahip olan otel çalışanları olarak saptanmıştır. Sonuç olarak, aşırı çalışma saatlerinin çalışanlarda iş doyumsuzluğuna neden olduğunu söylemek mümkündür.

\section{Şekil 2: Araştırma Modeli Sonuç ve Katsayıları}

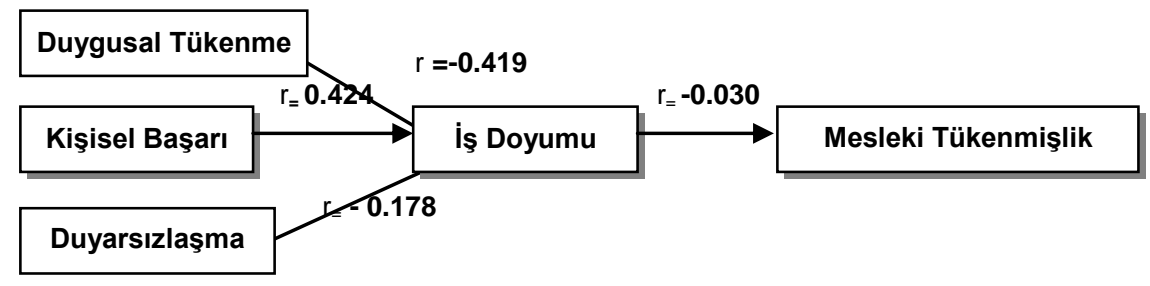


Çalışmanın hipotez testlerine toplu olarak bakıldığında; $\mathrm{H}_{1}$ "İ̧̧ doyumunun tükenmişlik üzerinde pozitif bir etkisi vardır", $\mathrm{H}_{2}$ : "Duygusal tükenme ile doyum arasında negatif yönde bir ilişki vardır", $\mathrm{H}_{3}$ : "Kişisel başarı ile doyum arasında aynı yönlü ilişki mevcuttur", $\mathrm{H}_{4}$ : Duyarsızlaşma ile doyum arasında negatif yönlü ilişki vardır", $\mathrm{H}_{7}$ : "Doyum değişkeni bakımından çalışılan bölümler arasında farklııı vardır" ve $\mathrm{H}_{8}$ : "Doyum değişkeni bakımından çalışma saatleri arasında farklılık mevcuttur" hipotezleri doğrulanmıştır. $\mathrm{H}_{5}$ : "iç doyum ve dış doyum değişkenleri bakımından erkek ve bayanlar arasında anlamlı bir farklılık vardır" hipotezi ile $\mathrm{H}_{6}$ : "Evli ve bekâr çalışanların doyum düzeyleri arasında anlamlı farklıık vardır" hipotezlerinin doğrulanamadığı görülmüştür. Araştırmanın bulgularının önerilen modeli de farklı katsayılarla onayladığı görülmektedir. Araştırmanın bulguları bu konuda yapılmış olan literatür kısmında yer verilen daha önceki çalışmaların bulguları ile de önemli ölçüde benzerlik göstermektedir.

\section{Sonuç ve Öneriler}

Bu çalışmada otel çalışanlarının genel doyum, iç doyum ve dış doyum düzeylerinin yüksek olduğu ortaya çıkmıştır. Çalışanlar işin niteliğinden, yöneticilerin tutumlarından, işletmenin kendilerine sağladığı çeşitli olanaklardan memnun oldukları ve işlerini zevkle yaptıkları sonucu ortaya çıkmaktadır. Mengenci (2015: 134) tarafından yapılan çalışmada hizmet sektöründe çalışanların, ilerleme, sosyalleşme ve ücret konusunda beklentilerinin karşılanması ile iş tatmini elde ettikleri ve bu şekilde işverenin müşterilere verilmesi gereken duygusal emeği daha derin ve doğal şekilde yansıttığı ileri sürülmektedir. Yine aynı çalışmada çalışanların yüzeysel ve derin davranış göstermelerinden iş tatminine ya da tatminsizliğine sahip olduklarının anlaşıldığı vurgulanmaktadır. Yüzeysel davranış gösteren personel düşük tatmin yaşamaktadır ve beklentileri karşılanan çalışan istenilen duygusal emeği göstereceğinden hizmet işletmelerinde rekabet avantajı elde etmesinde güçlenmesi anlamına gelmektedir (Mengenci, 2015: 135).

Çalışmada iş tatmini ve tükenmişlik arasındaki ilişkinin negatif yönlü olduğu tespit edilmiştir. Aynı şekilde Kaygın ve Naktiyok (2012) tarafından yapılan çalışmada negatif bir ilişki bulunmuştur. Bu çalışmada yapılan korelasyon analizinde çalışanların iş doyumu artıkça duygusal tükenmelerinin de azaldığı anlaşılmıştır. Üngüren vd. (2010: 2932)'nin yaptığı çalışma da iş doyumu yaşayan çalışanların tükenmişlik düzeylerinin oldukça düşük olduğu, işinden memnun olmayan çalışanların ise tükenmişlik düzeylerinde anlamlı bir yükselişin olduğu tespit edilmiştir.

Yapılan analizlerde çeşitli sonuçlar elde edilmiştir. Çalışanlarda iş doyumu arttıkça duygusal tükenme azalmaktadır. Otel çalışanlarının medeni durumları ile iç doyumları, arasında anlamlı bir farklılık olmadığı gözlemlenmiştir. Evli çalışanlar bekâr çalışanlara göre daha fazla iç doyum yaşamaktadırlar. Evli ve bekârlar benzer düzeyde dış doyum yaşamaktadırlar. Otel çalışanlarının medeni durumları ile genel doyum durumlarına arasında da anlamlı bir farklılık bulunmamıştır. Araştırmada ortaya çıkan önemli bir sonuç olarak otel çalışanlarının çalıştıkları bölüm ile iç doyum ve genel doyum arasında anlamlı farklılık tespit edilmiştir. Otel çalışanlarının çalıştıkları bölüm ile dış doyum arasında farklılık bulunmuştur. Bu çalışmada "mutfak ile ön büro" ve "mutfak ile güvenlik" bölümleri çalışanları arasında anlamlı bir farklılık olduğu sonucu ortaya çıkmıştır. Bölümler itibari ile değerlendirildiğinde, mutfak bölümü çalışanları en az iş doyumu yaşanan çalışan grubu durumundadırlar ve mutfak çalışanları daha az dış doyum yaşamaktadırlar. Mutfak çalışanları, yöneticilerin tutumundan ve idare biçiminden, kişin karşılığında alınan ücretten, çalışma şartları bakımından, üstlerin ve çalışma arkadaşlarının tutumları bakımından diğer bölüm çalışanlarına göre daha 
mutsuz görünmektedirler. Diğer taraftan, otellerin güvenlik ve ön büro bölümlerinde çalışanlar ise diğerlerine göre daha fazla iş tatmini yaşayan bölüm çalışanları olarak ortaya çıkmıştır. Bu bölümlerde çalışanların iç doyum puan ortalamaları dış puan ortalamalarına göre daha yüksek çıkmıştır. Sonuç olarak, bu bölüm çalışanları işlerinden, yöneticilerin ve arkadaşlarının davranışlarından, aldıkları ücretten diğerlerine nazaran daha memnun oldukları ortaya çıkmıştır.

Araştırmada iş doyumu ve demografik değişkenler arasında anlamlı bir farklılığa rastlanmamıştır. Sadece çalışma süresi ile iş doyumu arasında anlamlı bir farklılık bulunmuştur. Yapılan tek yönlü varyans analizinde çalışma süreleri ile dış doyum arasında farklılık vardır. Araştırmanın sonucuna göre "8" saatten fazla çalışanların işletmeden beklentileri de artmaktadır. Dolayısı ile yapılan iş karşılığı alınan ücret, yoğun çalışmaya rağmen takdir edilmeme ya da terfi olanağının olmayışı, çalışma şartları çalışanların işinden hoşnut olmamaları sonucunu ortaya çıkarmaktadır.

Çalışma ortamları ve işletme koşulları birbirinden farklılık gösterebildiği gibi, iş tatmini ve tükenmişlik araştırmalarında da farklı sonuçlar görülebilmektedir. İşletmelerin amaçlarından biri doğrudan tüketicileri mutlu etmenin yanında çalışanlarını da mutlu ederek sonuca ulaşma olabilir. Bu bakımdan iş tatmini, işgörenin mutluluğunun karşıı̆ı olarak meydana getirdiği hizmet çıktısının kalitesinde iyileşme olduğu için gerek otel ve gerekse diğer yöneticilerin iş tatmini yaratacak stratejilere odaklanmaları önemlidir. Çalışanların tatmini için otel yönetimlerinin bir işletme organizasyonunun "güdüleme (motivasyon) modeli" ve buna bağlı insan kaynakları politikasının olması önerilebilir. Ayrıca çalışanların istek ve beklentilerinin işe alım öncesi belirlenmesi ve iş sürecinde de çalışanlar ile empati oluşturulması yararlı olabilir. Ücret düzeylerinin artırıması, iş koşullarının iyileştirilmesi ve ödüllendirme, terfi vb. olanakların sağlanması yararlı olabilir.

Daha ileri akademik çalışmalar için önerilerimiz olarak; otel işletmelerinin yanı sıra turizmin diğer alanlarında (ulaştırma, restoran, eğlence vb. gibi) çalışanların tükenmişlikleri ile iş doyumları arasındaki ilişkilerin belirlenmesi ve hizmet alanları arasında farklılıkların olup olmadığının araştırılması ve de gerek iş tatmini değişkenleri, gerekse tükenmişlik değişkenlerinin neler olduğunun belirlenerek turizmin alt sektörleri arasında karşılaştırmalar yapılması yararlı olacaktır.

\section{Kaynakça}

Akgül, A. ve Çevik, O. (2003). İstatistiksel Analiz Teknikleri, Emek Ofset, Ankara.

Akıncı, Z. (2002). "Turizm Sektöründe İşgören İş Tatminini Etkileyen Faktörler: Beş Yıldızı Konaklama İşletmelerinde Bir Uygulama" Akdeniz İ.I.B.F. Dergisi (4) ss.1-25.

Amponsah, T., Kwesi, A., Francis, A. and Arthur, B.G. (2016). "Linking commuting stress to job satisfaction and turnover intention: The mediating role of burnout". Journal of Workplace Behavioral Health. Apr-Jun2016, 31 (2), ss.104-123.

Avcı, N. ve Akdemir, İ. (2014). "Konaklama işletmelerinde kurumsal sosyal sorumluluk algısının iş doyumu üzerine etkisi”, Ege Akademik Bakış, 14 (1), ss.125-135.

Besim, M., Seroğlu, K.,Tanova, C., Fethi, S., Uğural, S., Sıla, İ., Ekici, T. ve Küçük, N. (2015). Turizm Sektöründe İstihdam, Kuzey Kıbrıs Türk Cumhuriyeti'nde istikrarlı ve sürdürülebilir ekonomik büyüme sektör temelli analiz ve politika önerileri (Rapor), KKTC Başbakanlık, Doğu Akdeniz Üniversitesi, Gazimagusa, ss.104-107. 
Bianchi, R., Truchot, D., Laurent, E., Brisson, R. and Schonfeld, I.S (2014). "Is burnout solely job-related? A critical comment", Scandinavian Journal of Psychology, August, 55 (4), ss.357-361.

Cetin, İ. (2013). "Motivation and its impact on labour productivity at hotel business - A Conceptual Study" International Journal of New Trends in Arts, Sports \& Science Education, 2 (1), ss. 70-79.

Chen, C.F. and Kau, Y.L. (2012). "Investigating the antecedents and consequences of burnout and isolation among flight attendants", Tourism Management, Aug. 33 (4), ss. 868-874.

Civilidag, A. (2014). "Hotel Employees' Mobbing, Burnout, Job Satisfaction and Perceived Organizational Support: A Research on Hospitality in Turkey", European Scientific Journal, December, 10 (35), pp. 1857 - 7881.

Davis, K. (1988). Human Behavior at Work: Human Relations and Organizational Behavior, (5th ed.). New York, McGraw-Hill.

Doyle, P. (2004). Değer Temelli Pazarlama, Media Cat, İstanbul, Çev. Gülfidan Barış.

Jung H. and Lee, C.O. (2012). "Reducing burnout and enhancing job satisfaction: Critical role of hotel employees' emotional intelligence and emotional labor", International Journal of Hospitality Management, 31 (4), December, ss. 11011112.

Jung, H.S., Yoon, H.H. and Kim, Y.J. (2012). "Effects of culinary employees' role stress on burnout and turnover intention in hotel industry: moderating effects on employees' tenure". Service Industries Journal. Oct., 32 (13), ss.2145-2165.

Kandampully, J. and Hu, H.H. (2007). "Do hoteliers need to manage image to retain loyal customers?", International Journal of Contemporary Hospitality Management, 19 (6), pp.435-443.

Karagöz, Y. (2016). SPSS 23 ve AMOS 23 Uygulamalı İstatistiksel Analizler, Nobel Akademik Yayıncılık.

Karatepe, O.M. (2010). "Role stress, emotional exhaustion, and job satisfaction in the hotel industry: The Moderating Role of Supervisory Support", Hospitality Review, 28 (2), ss. 48-66.

Kaya, I. (2010). "Otel işletmelerinde işgörenlerin iş tatminini etkileyen işi bırakma eğilimi”, Çukurova Üniversitesi, Sosyal Bilimler Enstitüsü Dergisi, 19 (2), ss. 219 -236 .

Kaygın, E. ve Naktiyok, A.(2012). Tükenmişlik ve iş tatmini arasındaki ilişki: Akademik personel üzerinde bir araştırma. Çukurova Üniversitesi, I.I.B.F. Dergisi, 16 (1), Haziran, ss.99-118.

Kılıç, G., Pelit, E. and Selvi M.S. (2011). "The relationship between professional burnout and job satisfaction levels of employee: A study into employees in hotel enterprises", International Journal of Human Sciences, 8 (1), January, ss.440463.

Lee, J. and Ok, C. (2012). "Reducing burnout and enhancing job satisfaction: Critical role of hotel employees' emotional intelligence and emotional labor", International Journal of Hospitality Management, Dec, 31 (4), ss.1101-1112.

Leiter, M. P. and Maslach, C. (1988). "The impact of interpersonal environment on burnout and organizational commitment", Journal of Organizational Behavior, October, 9 (4), pp.297-308.

Lin, Y.S., Huang, W.S., Yang, C.T. and Chiang, M.J. (2014). "Work-leisure conflict and its associations with well-being: The roles of social support, leisure participation and job burnout", Tourism Management, Dec., N.45, ss. 244-252.

Locke, E.A. (1969). "What is Job Satisfaction?" Organisational Behaviour and Human Performance, 4 (4), pp. 309-336. 
Lu, A.C. and Gürsoy, D. (2016). "Impact of job burnout on satisfaction and turnover intention: Do generational differences matter?", Journal of Hospitality \& Tourism Research, 40 (2), February, pp.210-235.

Mengenci, C. (2015), "İ̧̧ tatmini, duygusal emek ve tükenmişlik ilişkilerinin belirlenmesi", Ege Akademik Bakış, 15 (1), ss.127-139.

Okray, Z. ve Abatay, G. (2015). Birinci basamak temel sağlık ve yataklı tedavi kurumlarında çalışan hemşirelerin tükenmişlik sendromu ve iş doyumlarının karşılaştırılması, Turkish International Journal of Special Education and Guidance \& Counseling, 4 (2), pp.49-56.

Özaydın, M.M. ve Özdemir, Ö. (2014). "Çalışanların bireysel özelliklerinin iş tatmini üzerindeki etkileri: Bir kamu bankası örneği”, Işs/etme Araştırmaları Dergisi, 6 (1), ss.251-281.

Pavesic, D.V. and Brymer, R.A., (1990). "Job satisfaction: what's happening to the young manager?" , The Cornell Hotel and Restaurant Administration Quarterly, 30 (4), pp.90-96.

Pizam, A. and Neumann, Y. (2016). "The effect of task characteristics on hospitality employees' job satisfaction and burnout", Journal of Hospitality \& Tourism Research, February 1, (40), ss.210-235.

Ramarumo, R.G. (2015). "The impact of organizational culture on job stress and burnout in graded hospitality establishments in the Freestate province", Thesis Dissertation (M.Tech) Tourism and Hospitality Management, Central University of Technology, Free State, South Africa. Bloemfontein.

Sümbüloğlu, V. ve Sümbüloğlu, K.(2005). Klinik ve saha araştırmalarında örnekleme yöntemleri ve örneklem büyüklüğü, Ankara, Alp Ofset Matbaacılık Ltd. Şti.

Tremolada M., Schiavo S., Tison T., Sormano E,. De Silvestro G; Marson P. and Pierelli, L. (2015). "Stress, burnout, and job satisfaction in 470 health professionals in 98 apheresis units in Italy: A SIDEM collaborative study." Journal of Clinical Apheresis [J Clin Apher], Oct. Vol. 30 (5), ss. 297-304.

Tuncer, M. ve Yeşiltaş, M. (2013). "Çalışma yaşam kalitesinin otel işletmesi çalışanları üzerindeki etkileri", İşletme Araştırmaları Dergisi, 5/1, ss.57-78.

Tutuncu, O. ve Kozak, M. (2007). "An investigation of factors affecting job satisfaction", International Journal of Hospitality and Tourism Administration, Vol. 8 (1), pp.1-19.

Üngüren, E., Doğan, H., Özmen, M. ve Tekin, Ö.A. (2010). "Otel çalışanlarının tükenmişlik ve iş tatmin düzeyleri ilişkisi". Journal of Yasar University, 17 (5): 2922-2937.

Yang, J.T. (2010). "Antecedents and consequences of job satisfaction in the hotel industry", International Journal of Hospitality Management, 29, ss.609-619.

Yeh, C.M. (2013). "Tourism involvement, work engagement and job satisfaction among frontline hotel employees", Annals of Tourism Research, July, Vol.42, ss. 214239.

Yirik, Ş., Ören, D. ve Ekici, R. (2014). "Dört ve Beş yıldızlı otel işletmelerinde çalışan personelin örgütsel stres ve örgütsel tükenmişlik düzeyleri arasındaki ilişkilerin demografik değişkenler bazında incelenmesi”, Journal of Yasar University, 9 (35), ss.6099-6260.

Zopitas, A., Constanti, P. and Theocharous, A. (2014). "Job involvement, commitment, satisfaction and turnover: Evidence from hotel employees in Cyprus”, Tourism Management, 41, ss.129-140. 